\title{
Role Of Radio Stations In Creating Awareness On Proper Solid Waste Management Practice In Yobe State, Nigeria
}

\author{
Abubakar Bappayo \\ MSc, Senior Lecturer, Abubakar Tatari Ali Polytechnic Bauchi, Bauchi State, Nigeria
}

Zanna Maidunoma

MSc, Senior Lecturer, College of Legal and Islamic Studies Nguru, Yobe State, Nigeria

\begin{abstract}
The study was conducted between the months of January-March, 2018 to examine the role of Radio stations in creating awareness on proper solid waste management practice in Yobe state Nigeria. Radio programs can have a direct impact on the perception, attitudes and behaviors of individuals enhancing their understanding of an environmental related issue. This leads to a potential behavioral change in waste management practices. The radio stations program provided a platform for the community to obtained in-depth knowledge to discuss issues concerns their environment with local council's officials in a way forward. This efforts were followed up by the radio stations and resulted in many of the concerns being addressed with improved infrastructure, agriculture, education, sanitation, safe drinking water, open defecation, waste disposal and management among others. Radio campaigns are strong instrument in raising public awareness on environmental related issues however, the role played by most of the Radio stations seem to be very low. Hence, this study was aimed to assess the roles of these Radio stations. However, there is fundamental role that media should play in promoting public awareness on solid waste management practices. The study was based on agenda setting theory, propounded by Max McCombs and Donald show in 1973. Data were collected through questionnaire and were analyzed using tabulation in form of frequency counts and percentages. Finding indicates that the public in Yobe state were aware of sensitizing campaigns by the media on solid waste management practices. The study also revealed that they have knowledge and that their attitude of illegal dumping of waste or poor garbage disposal on roads, city square, football field, into drainage, house hold compound, market areas, has change positively as a result of media sensitization campaign. Based on these findings, it is highly recommended that, since positive attitude toward proper solid waste management practices depended on regular radio enlightenment campaigns, frequent campaigns by the media were highly recommended.
\end{abstract}

Keywords: media campaigns, solid waste management, public awareness.

\section{JEL Classification: Y.}

\section{Introduction}

Solid waste management in urban centers worldwide continues to attract attention because it is mismanaged and yet it poses a danger to public health. In most of African towns, waste collection has for a long time been centralized (Mugambwa, 2009). The composition of wastes generated is mainly decomposable organic materials. This calls for efficient collection systems to avoid health, aesthetics and environmental impacts which would otherwise lead to community illnesses, resistance to treatment and reduced immunity.

Waste disposal and management is both an urban and rural problem (Chung, 2001). Every person is a potential generator of waste and thus a contributor to waste accumulation. To generate waste is one thing, the type of waste generated is another and yet also the way the generated waste is managed or disposed of is quite a different issue. It has more often than not turned out that the rate at which wastes are generated is far higher than the capacity to responsibly manage this waste (Chung, 2001). Waste is generated by, and from different sectors; domestic, commercial, industry and others and in many instances; the waste management responsibility has been left to the government or administrative authorities (Barr, 2004). There is growing consensus that both the immediate stakeholders in the issue of waste (the generators of waste) and those who manage their wastes well all suffer from the consequences of waste accumulation and poor waste management. For this matter, all residents need to join hands together with the authorities in dealing with this problem that has farreaching environmental and human health effects.

The problem of waste accumulation has not been left unattended to. Several mechanisms have been put in place to deal with this problem. Several organizations and companies, including private, government and Non- 
Governmental Organizations (NGOs) have come out to handle the problem of waste management. Despite the growing influence of media, especially radios in developing nations, it is not clear how these media houses have been used to create developmental awareness among the communities, including proper waste management. As Gershon (2010) acknowledges, radio stations all over the world, is deemed as the fastest, affordable and the best means of disseminating information to the dispersed heterogeneous population because it is flexible and it can cover a wide range of area. The attention of media to this problem is less and there are hardly any study examining the extent the media (especially radio stations) cover issues related to waste management and their impact on the proper waste management practices of the communities in Nigeria. This study intends to generate some empirical information about this issue and guide policy makers and next researchers on the same.

Conceptually, solid waste management (SWM) refers to the practices of the collection, transportation, treatment, final disposal and recycling of solid wastes (Muganbwa, 2009). Selin (2013) defines waste management as "the collection, transport, recovery and disposal of waste, including the supervision of such operations and the after-care of disposal sites, and including actions taken as a dealer or broker". The activity of SWM has been reported to have become a major problem in urban centers everywhere in the world (Barr, 2004) and this has led to community infections, loss of lives and increased disease burden (Selin, 2013). Proper Waste handling means the actual waste which is produced by users should be collected properly and carefully transported to an appropriate treatment plant in such a way that it is not hazardous to health and environment.

Given this background, the study seeks to establish the extent to which radio stations in Yobe state have successfully created awareness and changed the current community practices towards proper waste management. It will examine individual practices towards the formal and inform waste collection sites, what drives them to behave the way they behave and establish whether they have received any educational programs from radio stations warning them of the dangers of poor waste management practices or not.

\section{Statement of the problems}

There is enough evidence that the status of hygiene and sanitation is still poor in Yobe State, with huge piles of wastes dumped on roads, household compounds, city squares, outside hospitals, schools and almost everywhere. In Yobe State, solid waste disposal and management is thus both an urban and rural problem (Galadima, 2006). Every institution and household is a potential generator of waste and thus a contributor to this problem. Whereas the concept of wastes is almost a fact of life for as long as man exists, the challenges come from the categorization of waste, accumulation and disposed of these wastes.

In Yobe State, there are big heaps of garbage in front of business centers, streets, schools, hospitals, markets and residences (Galadima, 2006). Seepage (garbage leaks) from illegal dumping sites is common, which potentially contaminates the ground and surface water resources, posing serious health and economic threats. This problem of accumulated wastes and poor management and disposal practices are partly due to absence of a functional government system to manage domestic, municipal and industrial wastes, coupled with nonexistence of awareness campaigns about the national environmental laws and regulations. This problem is also due to increased population, business activities and settlement creation. The local people's, practices, skills, information and will for safe waste management are often not only inadequate but also poor. Individuals at the household and institutional levels lack familiarity with dangers of chemical substances which result from accumulated wastes. This also means that local populations behave inappropriately when handling their wastes.

Consequently, the risk of diseases arising from poor sanitation and environment especially during rainy seasons has increased in both towns and rural areas. The negative effects commonly neglected are the possible diseases such as typhoid fever, malaria, diarrhea, child birth defects, and cancer and so on. Apart from deliberate acts of some local people who simply damp their wastes anywhere they find, usual waste and garbage problems are also always in the news.

Therefore, there is a need for this study to establish the extent to which radio programs cover issues related to proper waste management practices, the extent to which the people in Yobe State receive these awareness messages and their reactions, as well as identifying the alternative ways of improving people's waste management practices.

\section{Purpose of the Study}


The purpose of this study was to assess and document the extent to which radio stations, through their programs, create community awareness about proper solid waste management practices in Yobe State.

\section{Objectives of the Study}

To establish the extent to which solid waste management awareness campaigns are embedded in the programs of radio stations in Yobe State.

\section{Research Questions}

To what extent do radio stations in Yobe State embeded proper solid waste management awareness campaigns in their programs?

\section{Theoretical scope}

The research study was based on the agenda setting theory formulated by Maxwell McCombs and Donald Show in 1972. The theory explain that the ability of the news media to influence the salience of topics on the public agenda. That is, if a news item is covered frequently and prominently, the public regarded the issue as more important.

\section{Significance of the Study}

The results to be obtained were used to generate possible ways on how communities can dispose-off their solid wastes in a responsible manner, with less or no damage to their health. The finding and recommendations of the study will be useful to Yobe State Ministry of Health and Environment (policy makers), Environmental Agencies and academicians.

\section{Literature Review}

\section{Waste Management Practices}

According to Freduah (2004) something can become waste when it is no longer useful to the owner or it is used and fails to fulfill its purpose. Freduah (2004) indicates that there are basically two types of waste namely liquid and solid waste. But for the purpose of this study, the focus is on solid waste. The term solid waste has been defined differently by various authors. According to Tchobanoglous et al. (1993) solid waste is any material that arises from human and animal activities that are normally discarded as useless or unwanted. According to Zerbock (2003), solid waste includes non-hazardous industrial, commercial and domestic waste including, household organic trash, street sweepings, institutional garbage and construction wastes. The term waste generally refers to all unwanted and economically unusable materials that result from human activities, discarded purposefully or accidentally into the environment (UNEP, 1994; Van Beukering, et al., 1999).

\section{Waste Management}

Waste management refers to the "collection, transportation, processing, recycling or disposal of waste materials"(Mugambwa, 2009). It ought to be appreciated that waste management practices differ for developed and developing countries, for urban and rural areas, and for residential and industrial producers. The volumes and types of waste in these different sources of waste justify the difference in the waste management practices. It therefore implies that the methods appropriate in one setting may be incompatible within another setting. It is imperative to take into consideration the context of the waste source, to arrive at an appropriate method.

Tchobanoglous et al (1993) further explained that the common types of solid waste include food waste, rubbish, ashes and residues and special waste as are explained below; Food waste: Food wastes are all the animal, plant or vegetable residues resulting from the handling, preparation, cooking, and eating of foods (also called garbage). The most important characteristics of these waste is that they are highly putrescible and will decompose rapidly, especially in warm weather. Often, decomposition will lead to the development of offensive odors. In many locations, the putrescible nature of these wastes will significantly influence the design and operations of solid waste collection.

Rubbish: Rubbish consists of combustible and non- combustible solid wastes of households, institutions and commercial activities. This excludes food wastes or other highly putrescible materials. Typically, combustible rubbish consists of materials such as paper, cardboard, plastics, textiles, rubber, leather, wood, furniture, and garden trimmings. Non-combustible rubbish consists of glass, tin cans, aluminum cans, ferrous and other nonferrous metals, and dirt. 
Ashes and Residues: These are materials remaining from the burning of wood, coal, coke and other combustible wastes in homes, stores, institutions, and industrial and municipal facilities for purposes of heating,

cooking and disposing of combustible wastes. These are referred to as ashes and residues.

Special waste: Special waste includes street sweepings, roadside litter, and litter from municipal containers, catch-basin debris, dead animals and abandoned vehicles. The Centre for Environment and Development (2003) has also classified types of solid waste based on origin (food waste, rubbish, ashes and residues, demolition and construction, agriculture waste), based on characteristics (biodegradable and non-biodegradable), based on the risk potential (hazardous waste). The Centre also enumerated sources of solid waste as residential, waste from shops, commercials establishment, hotels/restaurants/eating stalls, slaughter houses and others. This has confirmed the sources and types of solid waste outlined by Tchobanoglous et al (1993).

\section{The role of the media in environmental awareness and national development.}

It is pertinent to characterize the nature of mass media as an aid to understanding what roles they are or may be playing in social contexts. The mass media in Nigeria are urban-based. Radio remains the only widely accessible medium of communication that offers immediate contact with the rural populace.

Ciboh (2007), assert that communication media are the different technological process that facilitate communication between and are in the middle of the sender and the receiver of that message. The same media message might mean different thing to different people. Therefore there is need to bridge the gap between the knowledgeable persons and illiterates as Ciboh (2007) illustrates that only" a study of media campaign to promote awareness on environmental pollution which found that people learned very few facts highlighted in the campaign here was an unintended effect". The function of media has long time gone beyond that of educating, informing, entertaining and transmitting culture as traditionally ascribed to them. They are also now used to create awareness, stimulate interest and raise expectations as well as enlighten people on how to effectively manage their environment for national development.

These are the conventional social functions the media render to the public, but which is equally applicable in broader sense in national development pursuit. The role of media in national development lie in their capacity and capability to teach, manipulate, sensitize and mobilize people through information dissemination (Nwabueze, 2006). The media also chart a course for the public in line with the agenda setting theory, thereby creating in the minds of the people, issues that should be viewed as priority including developmental programme and policies. Instances of this role being presently played by media in Nigeria is the general millennium goal pursuit towards the year 2015, as proposed by the United Nations and incorporated as national policy by governments of member countries around the world.

Anders, (2010) posit that media are central public arena through which we become aware of environmental issues and the way in which they are addressed, contested and perhaps, resolved, He argues that environmental issues or problems do not simply emerge and announce themselves as issues requiring a social/political response in the form of legislation, research or a change in public practices and social arrangements. Problems and issues of various kinds only become recognized as such as problems or issues through talk, communication, discourse which define or constructs them as problems or issues for public and political concern.

Krishna (2013) agrees with this argument as he says "mass media can play a vital role in creating people's awareness about environment and communication of natural resources. It can serve this purpose by means of multi-channel regional and network service comprising programmes such as talks, interviews, plays and documentaries etc.

\section{Solid Waste Management Practices}

As discussed above, the key elements in solid waste management include: waste generation, storage, collection, transfer and transport, processing and recovery and final disposal. This means that when waste is generated it is first stored in either dustbins or skips. It is then collected and finally disposed off in landfills.

\section{Waste Generation}

Waste generation encompasses those activities in which materials are identified as no longer being of value and are either thrown away or gathered together for disposal (Momoh and Oladebeye, 2010). According to UNEP (2009), in 2006 the total amount of municipal solid waste (MSW) generated globally reached 2.02 billion tones, representing a 7\% annual increase since 2003. 


\section{Disposal}

It is the ultimate fate of all solid wastes whether they are residential wastes collected and transported directly to landfill site.

\section{Burning and dumping}

Apart from the controlled methods, which are mostly prevalent in the developed and developing countries, uncontrolled methods can often not be avoided especially in the developing world. In large parts of Africa, for instance, solid waste is still dumped in the open air, in the oceans/water bodies, or by burning it on site (Cointreau, et al., 1984). Such ways of disposal have irreversible and potentially harmful effects on both human health and the environment. These are clearly not methods that belong to sustainable waste management. It is alarming to note from a recent assessment that, such disposal methods are frequently employed in an estimated 175 sovereign nations and territories.

\section{Summary}

From the review of the literature above, solid waste collection and disposal are the critical issues in solid waste management. The various methods in disposing solid waste are: sanitary landfills, composting, recycling, incineration and others for managing solid waste. Even today people still resort to unscrupulous methods of disposing solid waste such as dumping into gutters, drains and roadside among others. Therefore, solid waste management should be the primary responsibility of all but not only the management authorities like the State and Local government. Furthermore, the provision of solid waste collection facilities, frequency of waste collection and equipment for managing solid wastes and the cost involved which are the corner stone in managing solid wastes were silent in the literature. However, the management is challenged by factors such as inadequate funds to support waste management, inadequate equipment's to support waste storage, collection and disposal, low collection coverage and irregular collection services.

\section{Methodology}

\section{Study design}

This study used the following research design descriptive cross sectional design, adopting quantitative approaches. It was also use a comparative and an expost facto survey design. The cross-sectional design was used to collect data across all the selected respondents at once, while the descriptive design used to find the identities and show the characteristics of respondents. The study used quantitative since data was analyzed using numbers. The comparative design used to establish the extent to which waste management practices for people who listen to related radio programs differ from those who do not listen to such, while the expost facto design used since data was collected on facts which already exist.

\section{Sample size determination}

The Sample size of the study was 300 respondents obtained by using the Slovene's formula.

\section{Sampling technique and procedure}

Purposive and convenient sampling techniques were used in selecting respondents. The procedure of reaching the individual from the community were based on convenient approach, on condition that the respondent was found to have a radio and is above 18 years. This is because there are no established sampling frames or list of all community members in the State, thus making random sampling for individual respondents impossible.

\section{Data collection instruments}

The main instrument of data collection was questionnaires. The questionnaire was divided into three sections; 1) Profile of respondents; 2) solid waste management practices; 3) Radio programs on waste management. Some questions were open ended and some closed ended.

\section{Data analysis techniques}

Quantitative data was entered into SPSS version 16.0 processed and analyzed. Frequency tables and cross tabulations showing frequency counts and percentage distributions was used to analyze and present the quantitative data. The role of radio stations towards proper solid waste management practices was determined using Pearson correlations and Chi-square distributions.

\section{Data analysis and presentation}


The main objective of the study was to assess the role of radio stations in creating awareness on proper solid waste management practices. 300 questionnaires were distributed and 280 questionnaires were returned. The respondents were asked to indicate their ages, gender, marital status, occupations and educational levels.

Table 1. Age distribution

\begin{tabular}{|c|c|c|}
\hline Age & Respondents & Percentage \\
\hline $18-25$ & 46 & $15.3 \%$ \\
\hline $26-35$ & 84 & $28 \%$ \\
\hline $36-55$ & 99 & $33 \%$ \\
\hline $55-$ above & 71 & $23.60 \%$ \\
\hline Total & 300 & $99.9 \%$ \\
\hline
\end{tabular}

Source: field survey, 2018.

The Table above shows that the respondents, 18 - 25 years have the least number of listenership only $15.3 \%$ listen to the solid waste management program on the radio. The category of age between 36 and 55 has the highest number of respondents with 99 constituting $33.5 \%$ followed by the category of $26-35$, representing $28 \%$. This is because these categories, $26-35$ and $36-55$ have more concern in listening to solid waste management program on the radio than the category of $18-25$ years, which comprises young people who do not pay much attention to such programs.

Table 2. Occupation of the respondents

\begin{tabular}{|c|c|c|}
\hline Occupation & No of respondents & Percentage \\
\hline Civil servant & 107 & $35.6 \%$ \\
\hline Traders & 81 & $14.6 \%$ \\
\hline Farmers & 44 & $12.6 \%$ \\
\hline Unemployed & 38 & $10 \%$ \\
\hline Students & 30 & $99.8 \%$ \\
\hline Total & 300 & \\
\hline
\end{tabular}

Source: field survey, 2018.

The above table shows that the highest respondents in this research are civil servants as indicated 107 filled the questionnaires properly. They respondent $35.6 \%$ of the entire respondents, this is because the times of broadcasting this program, Saturday and Sunday where most of them are at home. Traders are the second highest respondents, 81 representing $27 \%$ many of them listen to the program in their shops other categories of occupation were: Farmers, (44) representing 14.6\%, students (30) representing 10\% and unemployed (38) which is $12.6 \%$.

Table 3. Educational levels

\begin{tabular}{|c|c|c|}
\hline Education & No respondents & Percentage \\
\hline Primary certificate & 105 & $35 \%$ \\
\hline Secondary or Grade II Certificate & 105 & $35 \%$ \\
\hline Certificate & 20 & $6.6 \%$ \\
\hline Diploma & 40 & $13.3 \%$ \\
\hline NCE & 40 & $13.3 \%$ \\
\hline HND & 24 & $8 \%$ \\
\hline Degree & 34 & $11.3 \%$ \\
\hline Postgraduate & 19 & $6.3 \%$ \\
\hline Total & 300 & $99.8 \%$ \\
\hline
\end{tabular}

Source: field survey, 2018.

The above table indicates that the highest listeners are SSCE which is (105) 35\% and follow by Diploma and NCE which is 40 respondents each. HND holders has 24 respondents and while Bachelor Degree has 34 respondents and postgraduate has 19 respondents, other category are primary school certificate holders which has 18 respondents and certificate holders has 20 respondents represented $6.6 \%$. 
Table 4. The role of radio in creating awareness on proper solid waste management.

\begin{tabular}{|c|c|c|}
\hline \multicolumn{3}{|c|}{ Respondents' views } \\
\hline 1. Strongly disagree & 37 & $12.3 \%$ \\
\hline 2. Disagree & 62 & $20.6 \%$ \\
\hline 3. Agree & 70 & $23.3 \%$ \\
\hline 4. Strongly Agree & 125 & $41.6 \%$ \\
\hline 5. Neither agree nor disagree & 6 & $2 \%$ \\
\hline Total & 300 & $99.8 \%$ \\
\hline
\end{tabular}

Source: field survey, 2018.

Respondents were also asked to give their views on what role does radio perform in creating awareness on solid waste management. And the research finding reveal that the majority of the respondents strongly agreed that radio create awareness, enlightening, educating, sensitizing and mobilizing the people on how to dispose and manage their solid waste with little or no damage to their health and environment.

\section{Conclusion}

This study revealed that, residents of Yobe state Nigeria were fairly satisfied with the time allocated to environmental related programs by the home-based Radio stations in creating awareness on proper solid waste management practices. However, Radio airtime does not have much impact on improving the waste management practices. The study also revealed that the enlightenment campaigns on Radio stations enhanced the situation with regards to waste management practices. In answering the research questions of the study, it was revealed that, campaigns on Radio stations with regards to raising people's awareness on proper solid waste management practices were very much effective in changing attitudes of the residents in that line. The Radio enlightenment campaigns in the area under study have changed the attitudes and behaviors of the residents on waste management practices to extent that poor disposal of waste by the residents has significantly reduced as compared to some years back and frequent incidences of cholera, dysentery and diarrhea are no longer frequent because of the radio enlightenments campaigns.

\section{Recommendations}

Based on the findings made by this study, the following recommendations are hereby proffered.

1. Radio stations should increase their coverage on environmental related issues by designing more relevant and educative programs aimed at raising or educating the local communities in terms of the need to imbibe the spirit of proper waste management practices

2. The Ministry of Health, Environment as well as other related NGOs should support and encourage the Radio stations to provide more airtime to waste management practices especially by sponsoring such programs.

3. Some of the Radio stations do not have direct programs on environmental related issues and for those who have, the time allocated for such programs were short such that the programs are broadcast weekly and even occasionally. Hence, Radio stations should strengthen the enlightenment campaigns on solid waste management practices by creating more programs on that aspect.

4. Radio enlightenment campaigns should focus on the dangers of indiscriminate waste disposal on the health of the residents of Yobe state and redesign their programs to encompass discussions, interviews with experts on environmental issues, Radio Links, Dramas as well as public participations. This strategy can help to influence people's attitude and behavior in ways that promote environmentally sustainable societies.

5. The study also discovered that attitudes of indiscriminate waste disposal by most of the local communities arise as a result of lack of specially allocated refuse dumping sites in most of these areas under study. Thus, it is recommended that Governments at all levels should provide refuse dumping sites in each of these locations at places very much accessible to the local residents.

\section{References}

1. Anders Hansen (2010). Environmental, Media and Communication. Routledge Madison Avenue. USA.

2. Barr, S. (2004). What we buy, what we throw away and how we use our voice; Sustainable Household waste Management in the UK. Sustainable Development, 12, 32-44. 
3. Centre for Environment and Development (2003). Study of the Attitude and Perception of Community towards Solid Waste Management. A case study of Thiruvananthapur city-Phase II. Submitted to Kerala Research Programme on Local Level Development.

4. Ciboh, R. (2007). Mass Media in Nigeria perspectives on growth and development. Makurdi: Aboki publishers.

5. Coinstreau, S. J., Gunnerson, C. G., Huls, J. M. and Seldman, N. N. (1984). Recycling from Municipal Refuse: A State of the Art Review and Annotated Bibliography. World Bank Technical Paper No. 30. The World Bank, Washington, D.C.

6. Chung, S.S. and Poon, C.S. (2001). Coomment: Accounting for the shortage of solid waste disposal facilities in sourthan China. Environmental.

7. Freduah, G.(2004). Problems of Solid Waste Management in Nima, Accra. University of Ghana, Legon.

8. Galadima, A.J. (2006). Coverage of Environmental Issues and Problems by Nigeria News Magazine. A content analysis in the Nigeria Journal of Communication.

9. Gershon, F. et'al (2010). Radio and Development- A concept Paper Prepared for the International Development Research Centre (IDRC) August 2011 (Updated March 2012).

10. Kumah, A.M.(2007). The Situation of Solid Waste in Ghana. Accra, Ghana.

11. Kreshna, M. (2013). Media and Environmental Awareness. (An article). Creative Commons. www.groundreirt.com/health.

12. Medina, M. (2000). Globalization, development and Municipal Solid Management in third world cities.

13. Mensah, A. and Larbi, E. (2005). Solid waste disposal in Ghana. Accessed on 24th April, 2014. from www.trend.wastsan.net.

14. Miller, G. T. (2002). Living in the Environment: Principles, Connections and Solution. Wadsworth Group Brooks / Cole, 12th Edition.

15. Momoh, J.J. \& Oladebeye, D.H. (2010). Assessment of Awareness, Attitude and Willingness of People to Participate in Household Solid Waste Recycling Programme in Ado-Eketi, Nigeria, in the Journal of Applied Sciences in Environmental Sanitation. Jakarta, Indonesia.

16. Mugambwa, E.K. (2009). What is Waste Management? URL:http://www.nemaug.orgindex.phpoption=com_content\&view=article\&id=69: whatis-waste-management \&catid=1:1atest-news\&Itemid=59. Accessed 25th April, 2014.

17. Nwabueze (2006) cited in Isa M. Inuwa (2007). The role of media in national development: A paper presented at a workshop on the event of $27^{\text {th }}$ leadership programme organized by LEAP Africa on Tuesday July 24, 2007 at British Council, Kano.

18. Omenesa, Z.E. (1997). Radio Script Writing and Production. Proceedings of the Orientatio and Refreshers' Courses for the NEARLS staff, February 17-22, ABU, Zaria.

19. Selin, E. (2013). Solid waste management and health effects- A qualitative study on awareness of risks and environmentally significant behavior in Mutomo, Kenya. Unpublished Bachelor of Environmental and Health Protection thesis, UMEA University, Kenya.

20. Tchobanoglous, G., Theisen, H. and Vigil, S. (1993). Integrated Solid Waste: Engineering principles and management issues. McGraw-Hill Publishing company, USA.

21. UNEP (United Nations Environmental Programme) (1994). Environmental Data Report 1993/1994. A Report for Global Environmental Monitoring System. Brazil. Blackwell, Oxford, UK.

22. United Nations Environmental Programme (UNEP) (2009). Developing Integrated Solid Waste Management Plan Training Manual, Volume 2: Assessment of Current Waste Management Systems and Gaps Therein. Osaka/Shiga, Japan.

23. Zerbock, O. (2003). Urban Solid Waste Management: Waste Reduction in Developing Nations. Accessed on 18th July, 2013 from www.cee.mtu.edu. 